\title{
Economy
}

\section{Economy Today}

\section{An Interdisciplinary Approach}

to Contemporary Economic

Challenges

edited by Piotr Urbanek

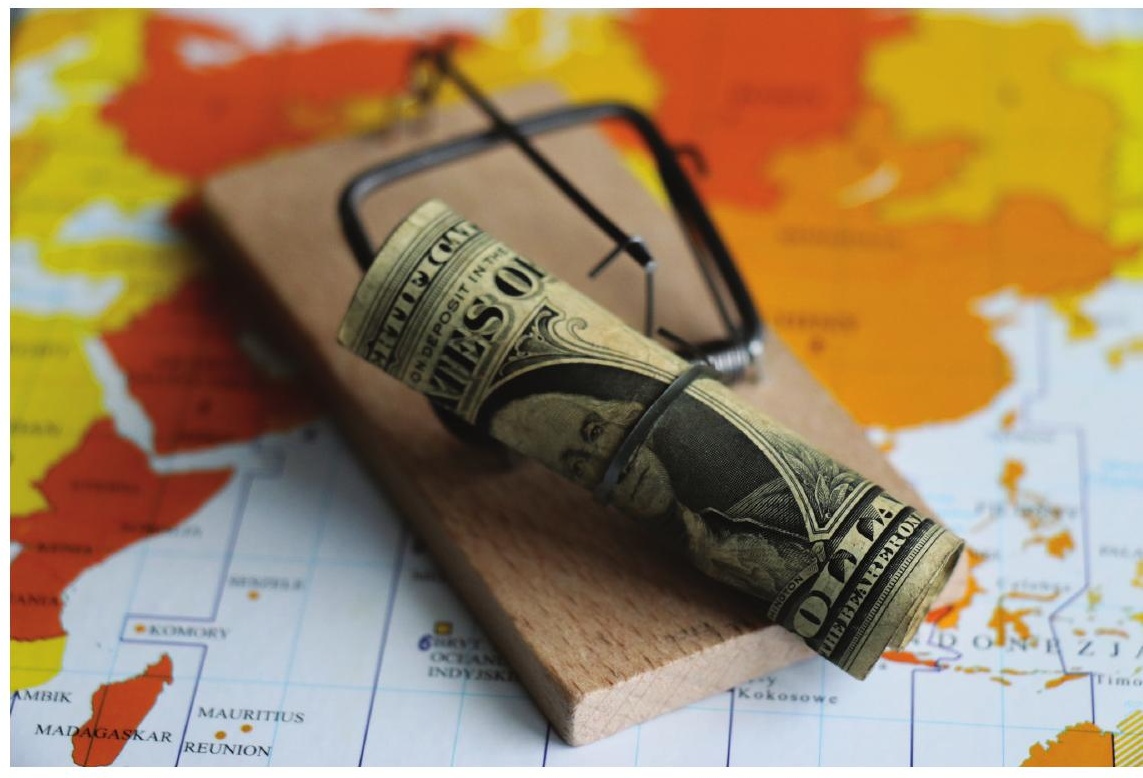




\title{
Social and ethical issues in management
}

\section{Corporate social responsibility in the management of Norwegian government pension fund global}

Julita Fiedorczuk*

\begin{abstract}
This article is an attempt to analysis socially responsible activities in the GPFG with reference to the specifics of the Norwegian economy. For this task was used the self-created tool dividing the dimensions of the concept of CSR and proposing suitable measurement methods for each of them. The phenomenal economic system in Norway (Scandinavian model, welfare state, egalitarianism, sustainable development) has a material impact on the quality and effectiveness of realisation responsible investment in the fund. The findings of the research can be used as a basis for more advanced analysing in other articles.
\end{abstract}

* MA/MSc, e-mail: fiedorczukjulita@uwb.edu.pl, University in Bialystok, Poland. 


\section{Introduction}

Corporate social responsibility is popular theme of discussion increasing amount of economics theorists and practitioners. The increase in interest in this subject is a response to the growing awareness of the role of balance in sustainable development, which is hard to achieve with a large share of the market mechanism in the economy. Disparities of the economic, environmental and social dimensions inhibit the growth and limit development. The concept of corporate social responsibility (CSR) tries to mitigate inadequate relations between these three basic dimensions of economic activity.

A specific example of an organization implementing the assumptions of CSR is Global Government Pension Fund in Norway. The analysis of the Fund in terms of responsible practices can be very useful in understanding the phenomenon of the Norwegian economic system. Management of the government fund is closely associated with the policy of the country. Norway is an example of a state, which consistently attracts the attention of researchers ${ }^{1}$, arousing misunderstanding of ability to achieve economic success while respecting the environment and the needs of the individual.

\subsection{The Government Pension Fund Global in Norway's and the world's economy}

In the face of the limited natural resources and Dutch disease, creation GPFG is the manifestation of responsible distribution Norwegian wealth from the raw material sector distribution between generations, in a way that provides sense of security and prosperity for future generations guarantee.

A Government Pension Fund (consisting of the Global and the Norwegian Fund) was established in 2006 on the basis of the Government Petroleum Fund, which was founded in 1990 (NBIM, History). The first transfer of accumulated capital to the fund in 1996 was a reaction of the authorities to the situation deteriorating terms of trade, the specter of the Dutch disease and the loss of competitiveness in exports, as a result of capital inflows from the sale of raw materials. (Araszkiewicz, 2008, p. 124-125) the Fund has been accumulating capital for 25 years and also

1 For example R. Whitley (2000) and D. Soskice (1999, p. 100-134) who predicted the imminent defeat of the Norwegian system. 
promotes balance between maximizing profit in the long term and investing in a socially responsible way only.

Great significance in the GPFG is primarily a consequence of the size of the Fund. The market value of fund has exceed the GDP of the country since 2005 year, constituting $220 \%$ of gross domestic product in 2013 . (Government.no, Market...) Government Pension Fund Global in 2014 was the second largest government fund with respect to net assets in the world. (SWF, 2014). GPFG market value increased from 440 billion at its inception to 5478 billion NOK in the first half of 2014 years (Government. no, Market...). The largest share of market value of the fund is an inflow of capital from outside. In 2013, the transfer of capital from the budget to fund accounted for approximately $34 \%$ of revenues in the period (Norges Bank, 2014, p. 11).

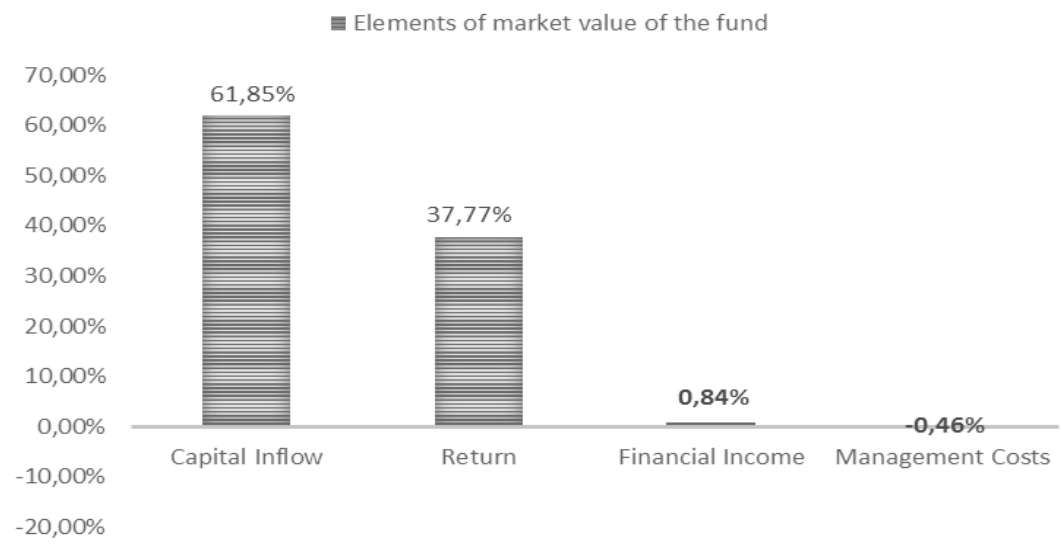

Figure 16. 1. The market value of the fund since its inception to the first half of 2014 (in \%)

Source: own based on Government no., Market value, https://www.regjeringen.no/en/ topics/the-economy/the-government-pension-fund/government-pension-fund-global-gpfg/ market-value-and-capital-inflow/id696852/.

The Fund and Norwegian State has an impeccable reputation, resulting in a large trust investing. The investment strategy besides the logic of conduct clearly explained in the investment process, presents the simple rules of interaction with investors and the environment. Financial factors such as a high rate of return and a moderate level of risk contribute to the capital allocation in the fund (the average real rate of return from 2012.06 to 2013.06 was 13.26\%) (Govermnent. no, Fund...). However, the added value is worthy of special attention, which is generated by active operation of Norges Bank Investement Menagement in all areas. Active mamangement has been getting more 
offensive, what was emphasised by General Director NBIM Yngve Slyngstad'a ${ }^{2}$ in 2008 , who in a fight with the crisis changed the strategy in a more plentiful of initiative. Under his leadership, the "Norwegian style" of fund management has become an one of the best international example of effective governance of sovereign wealth fund.

The Fund is an integral part of the Norwegian budget. In some situations, there are transfers of capital from the Fund to the budget. Despite the name, there is no formal fund pension obligations. No decision has yet been taken as to when funds will be used (Fiedorczuk, 2014, p. 71).

GPFG plays an important role in the national and global economy. By investing in selected companies abiding by ethical rules, the Fund sends signals to promote responsible behaviour among shareholders. The size and scope of the fund helps to effectively promote the validity of long-term implication of the concept of CSR in the world. Moreover, the global reach of the Fund's activities contribute to balancing the size of the business in order to provide the conditions for sustainable economic development.

\subsection{Selected points of view of corporate social responsibility in the theory of economics}

Corporate social responsibility is a relatively new concept. A proper sense of this term appeared in the mid-twentieth century. H.R Bowenis considered to be the founder of the concept, which tried to explain in Social Responsibilities of the Businessman. His proposal of definition was first explanation the most approximate to present understanding of SRC concept. (Rudnicka, 2012, p. 39). This does not mean that previously did not appear examples of socially responsible activities or attemptsof defining. However, they were fragmentary and without awareness of the meaning of the concept as a whole.

There is a large amount of definitions of CSR concept in the literature, due to the qualitative character of the responsibilities and wide interpretation possibilities. In some studies the concept is a trend in management in others it is treated as a supplement to a free market economy model of ethical and social elements, in others is a needed framework to introduce s-called "soft regulation" (Filek, 2013, p. 118). The wide range of meanings

2 In July 2013, Slyngstad was ranked number three on the Sovereign Wealth Fund Institute's Public Investor 100. Slyngstad has been listed as one of the top 100 most influential institutional investors worldwide. 
for corporate social responsibility resulted in the appearance of more specific terms, for example: Social Responsible Investment, Corporate Social Rectitude, and Corporate Social Performance. Difficulty in defining the concept also cause problems with its measurement. A review of the literature and reports, analysis and publications of institutions dealing with this issue leads to the conclusion that there is no universal method to measure the implementation of the concept.

According to the definition adopted by Davis and Blomstrom the 1975 CRS is obligation to make such decisions and actions that will result in attention to self-interest and the public welfare (Davis and Blomstrom, 1975, p. 13). Also in this article it is assumed, that the activity is socially responsible, when benefits it the individual and society's interest. Due to the high degree of generality explanation of the adopted concept, it was divided into smaller parts to facilitate measurement.

According to the results of A. Dahlsrud's research (from the article How corporate social responsibility is defined) most synthetic definition adopted the European Commission in 2001. In this definition are included all five dimensions of the concept: economic, social, environmental, stakeholders and voluntariness (Dahlsrud, 2008, p. 7). According to the definition of the European Commission responsible social action must be applied on a voluntary basis, including the social and environmental aspects of commercial activities and contacts with stakeholders (Commission of the European Communities, 2001, p. 6).

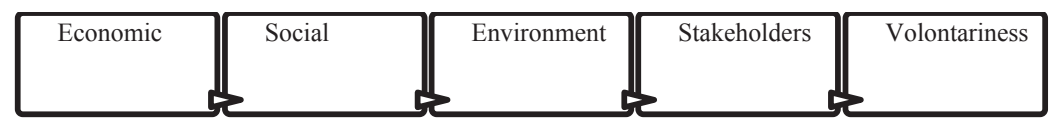

Table 16.1. The dimension of Corporate Social Responsibility Source: Dahlsrud (2008), p. 7-13.

According to a review of the empirical work by A. Wąsowska and M. Pawłowski operationalization methods of corporate social responsibility can be divided into four basic groups: (1) measurement charity activity - expenditure on charitable activities; (2) measurements based on existing databases and reputation index - base created by organizations and agencies; (3) surveys - surveys at the level of the organization and (4) monitoring of disclosure - financial statements and other reports (Wąsowska and Pawłowski, 2011, p. 15-16).

The combination of results of the work Dahlsrud's and Wąsowska, Pawłowski can create a scrupulous measurement tool, which is used in 
the next part of the article. To exhaustive and comprehensive analysis

CSR proper methods were selected to each dimension of the concept.

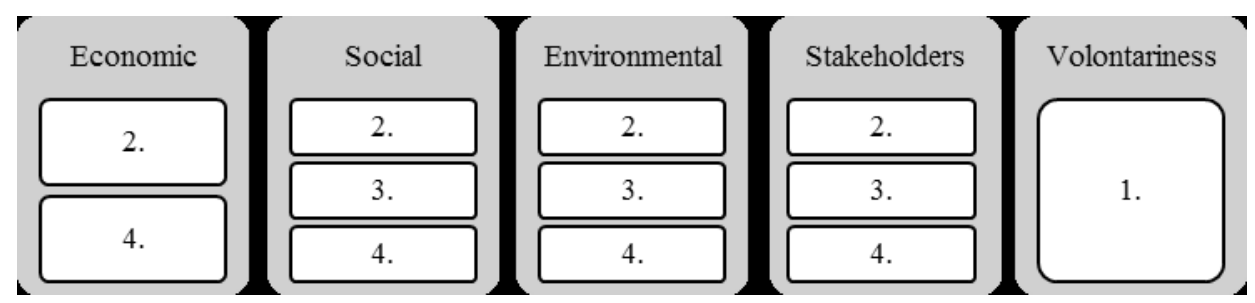

Table 16.2. The proposal tool to analyse the level of CSR realisation Source: own, based on Wąsowska and Pawłowski (2011, p. 15-18); Dahlsrud (2008, p. 7).

The proposed procedure allows for a more detailed evaluation. The use of one method to measure all dimensions of responsible action does not give rise to valuable conclusions. Therefore, it seems important to fragment the areas of CSR.

\subsection{Corporate social responsibility in Government Pension Fund Global}

The Fund is selected for the analysis and not accidentally. The idea of the creation and operation of the fund is proof of justice and accountability. The concept of CSR is a component of the operation ideology, which is exhibited in the investment strategy. The ethical principles are strictly adhered to. The guardian of responsible practices is an independent cell - the Council of Ethics. The Council decides to exclude from the investment portfolio entities whose activities go beyond the accepted area of freedom of taken decisions and makes publicly available a list of executed companies and governments (Council of Ethics, 2015).

The GPFG is particularly active in voluntary and an additional six areas: well-functioning and efficient markets, risk management, climate change, water management, respect for children's rights, equal treatment of stakeholders and stakeholder influence and responsibilities of the board (NBIM, 2015, Responsible...).

Norges Bank Investment Management, which manages the fund is a signatory to the Principles for Responsible Investment (PRI PRI, 2015). Ethical principles include the content of the precepts of the UN Global Compact (OECD, Principles...). NBIM manages the fund using the 
OECD Guidelines on Corporate Governance and Multinational Enterprises (OECD, Guidelines...). NBIM applies reports under the initiative of the Global Reporting Initiative (GRI). Sustainability reporting is a vital step for managing change towards a sustainable global economy - the one that combines long term profitability with social justice and environmental care.

The GPFG is one of the most transparent fund in the world (SWFI, 2014; Behrendt, 2010, p. 6) and received one of the Truman Oil solvents resistance rating of SWF Scoreboard (Truman, 2007, p. 15). It publishes and complete lists of its holdings as well as its voting records in its quarterly and annual report. The GPFG publishes the benchmark portfolios used to measure its performance against.

Only four of the five dimensions were analysed, because available information was not found, moreover, a response from NBIM about the (Previous chapter). According to the fact that the GPFG is one of the most transparent fund in the world, using only two methods is not very risky and allows us to draw the right and rather true conclusions. The volontriness dimension was bypassed because available information were not found, moreover response from NBIM about adopted and implemented definition of CSR were not received. So there is no basis to confirm that charity activity is an element of it. Surveys were sent but response from NBIM was not received.

\begin{tabular}{|c|c|}
\hline Dimension & Measurement charity activity (1.) \\
\hline \multirow[t]{2}{*}{ Volontariness } & Measurement was not performed due to lack of the required data. \\
\hline & Measurements based on existing databases and reputation index (2.) \\
\hline Economic & \multirow{4}{*}{$\begin{array}{l}\text { CFA Institute (GIPS) } \\
\text { Principles index from RI Transparency Report (PRI) } \\
\text { Fund Management in } 21^{\text {st }} \text { century (ISVA for WWF) }\end{array}$} \\
\hline Social & \\
\hline Enviromental & \\
\hline \multirow[t]{2}{*}{ Stakeholders } & \\
\hline & Surveys (3.) \\
\hline Social & Method was used, but not replied feedback \\
\hline Environmental & - \\
\hline \multirow[t]{2}{*}{ Stakeholders } & Method was used, but not replied feedback \\
\hline & Monitoring of disclosure (4.) \\
\hline Economic & $\begin{array}{l}\text { Performance Results (NBIM), Presentation of investment performance in } \\
\text { compliance with Global Investment Performance Standards (NBIM), Verifi- } \\
\text { cation Report (the Spauldnig Group), List of excluded and observed com- } \\
\text { panies (NBIM) }\end{array}$ \\
\hline
\end{tabular}




\begin{tabular}{|l|l|}
\hline \multicolumn{1}{|c|}{ Dimension } & \multicolumn{1}{c|}{ Monitoring of disclosure (4.) } \\
\hline Social & Expectations Document: Children Right, The list of excluded investors. \\
\hline Enviromental & Annual Reports: Climate changes, Water Management \\
\hline Stakeholders & $\begin{array}{l}\text { Annual disclosure of voting record, Submissions to ministry, Stakeholder } \\
\text { Advocacy, Negative screening }\end{array}$ \\
\hline
\end{tabular}

Table 16.3. The methods used to measure the implementation of the concept of CSR with the division of Dahlsrud dimensions Source: own tool created on definitions and division Wąsowska and Pawłowski (2011, p. 15-18); Dahlsrud (2008, p. 7) (Previous chapter).

The results of the review of reports and disclosures prepared by itself allow for the conclusion that the responsible activities of GPFG is very mature. The concept of CSR occupies a strategic place in the mission of the fund, which organizes the organization and lines of action. The fund has a high degree of transparency in all six areas of responsible taken actions. However, there is lack of positive screening in Fund performance. Clarity and understanding of the practices and expectations of the stakeholders is in the form of simple messages in the form of, strategy, ethical principles, quarterly and annual reports, discussion notes, features. The Fund sends signals of respecting only social responsible behaviour among stakeholders by investing only in selected companies that abide by ethical rules. NBIM makes the decisions based on recommendations from the Council of Ethics. Council of Ethics appoints excluded company from the fund's investment universe or places company on an observation list.

The evaluation social responsible activity of GPFG based on existing databases and indexes reputation effects slightly worse results than by monitoring disclosures.Among sovereign wealth funds Government Pension Fund Global is recognized as a leader in the using and promotion of the CSR concept. However, in comparison with all types of entities involved in the assessment by international organizations, the Fund is listed relatively lower in the hierarchy. From the measurement results based on the analysis of existing data can also be noted that the Fund is the executor of the concept on a global scale. However, there are areas of activity, which should improve mainly environmental activities and introduce reporting positive ${ }^{3}$. In the international organizations reports also emphasize the particularly positive practice in the Fund. A report commissioned by WWF reveals the high standards of behaviour in inter-

3 This recommendation was supported by Robert Stand (professor of corporate responsibility and business ethics at university of Minnesota) in the letter to UK Financial Times in 2008. 
actions with stakeholders. The Fund seeks to be an active manager, which performs effectively organizing meetings with investors and shareholders to dialogue and acknowledge expectations.

The ethical foundation is fundamental to the Government Pension Fund Global. The fund invests and exercises its ownership rights responsibly, because the fund's investments are about the future and belong to future generations. The main aim of management is the contribution to efficient and well-functioning markets and promoting work on international standards for responsible investment. Wide use of the concept of CSR in the Fund, as a rule also resulted in the development of reporting. The importance of corporate social responsibility reporting in today's financial markets is rising.

\subsection{Considerations of responsible activities in Government Pension Fund Global}

The maturity of the corporate social responsibility and naturalness of it application in the Fund is result of many of conditions. The ethical basis for the Norwegian CSR-policy derives from the inviolability of human dignity. Norway is one of the first countries to develop a coherent policy on Corporate Social Responsibility (CSR) in a global economy. Part of this policy is to base the investments of the Norwegian Government Pension Fund on an ethical foundation (Norwegian Embassy).

An analysis of the factors influencing the style of fund management should begin from Norwegian culture. Culture is a determining factor in the way of thinking, attitude and ability of a nation to develop, which is confirmed by the results of the research presented in the book Culture is important (Harrison and Huntington, 2003, p. 412). The word justice and equality are deeply rooted in the culture of social - democratic Norwegians. Religion and protestant ethics in harsh environmental conditions developed specific attitudes. On the one hand, society had to count only on themselves to fulfilling their duties by hard work of and the second, functioning without violating the standards of social conduct (Angel, 2013, p. 25-27). Thedifficulty in being self-sufficient and independent in such Norwegian hard conditions in the past resulted in acceptance of majority participation the state and institutions in the market. So a huge part of the responsibility for citizens and risk of satisfy all the needs of society were moved on the state duties. From the same reasoning society fully accepts the redistribution of income and participates in the welfare statecosts.

On the border between cultural factors and lifestyle is situated Norwegians concern for the environment. Both the state and society treat nature 
as a national heritage. The environmental aspect in Norway has gained strategic importance. In 1972, Norway was the first country in the world to create a ministerial unit dealing with issues of responsibility for the environment (Report No. 14, 2007). The need for the establishment of the unit due to the economic culture and traditions of Norway, whose main purpose is to manage, so that future generations can enjoy the unchanged nature (Harrison and Huntington, 2003, p. 70, 74).

The high standard of social responsible activities at organisation level in Norway is depended on state, which set an example responsible attitude 4 . Even in legislative process in Norway, the governments are carried out on the basis of democratic discussion with the public. This dialogue is called Nordic consensus. Thus, decisions by public authorities are a reflection of the views of citizens. "Happy democracy" in Norway is based on careful listening needs of the people at the level of individuals, groups (unions) and local communities. The Norwegian reality disputes are resolved parliamentary and very important decisions consult with citizens, eg. by referendum. The State has the support of the parties advisory bodies, which are intermediaries between the private sector (Nowiak, 2011, p. 130-134). Such consultations make public choices are relevant and acquire a more practical dimension. It is not surprising, Norway is the most democratic country in the world (Democracy Index, 2014) $)^{5}$, with one of the highest levels of happiness of citizens ${ }^{6}$, respect for gender equality (GDI in 2013) ${ }^{7}$, the world's highest indicator of quality of life (HDI in 2014) ${ }^{8}$ and the level of sustainable development of the country (HSDI in 2010) ${ }^{9}$.

Social attitudes of the state and public institutions are worth describing. The relatively high proportion of intervention in the economy is social

4 The Labour Market Act, Social Welfare Act, The Pollution Control Act, The Product Control Act, The Greenhouse Gas Emission Trading Act, The National Insurance Act, The Norwegian General Civil Penal Code, The Norwegian Agency for Development Cooperation.

5 According the Global Democracy Ranking 2014, http://democracyranking.org/ wordpress/?page_id=831.

6 II position in the world according J. Helliwell, R. Layard, J. Sachs, World Happiness Report 2013, http://unsdsn.org/wp-content/uploads/2014/02/WorldHappinessReport2013_online.pdf, p. 2.

7 According the Ranking of UNDP 2014, Gender-related development index (GDI), http://hdr.undp.org/en/content/table-5-gender-related-development-index-gdi.

8 According the UNDP, Human Development Report 2014, http://hdr.undp.org/en/ countries/profiles/NOR.

9 According the Our World, 2010 Human Sustainable Development Index, http://ourworld.unu.edu/en/the-2010-human-sustainable-development-index. 
manifest of absolute trust citizens. The market is a very effective mechanism for allocation in the short term, but in a long time horizon is not able to protect nature and human satisfaction.Only the state is able to effectively manage free goods and represent the interests of the whole community in the long run (Chmielak, 2002, p. 80-82).

The Norwegian welfare state model works in condition of high developed economy and well organized public sector. Norway has long experience in the functioning and management of the public sector. Important is social prestige and high consideration attributable to the state officials fulfilling a social mission (Nowiak, 2011, p. 136-137). Social responsibility is not just a dead note, but also style of work even at the lowest level of its implementation. It leads to higher quality of work and reduces the possibility of acting to the detriment of the state.

Being a responsible country is required meeting expenses for the implementation of responsible initiatives. A highly developed economy is not a prerequisite for the exercise of CSR principles. Norway is one of the richest economies in the world ( $2^{\text {nd }}$ place in the world in 2013 in terms of GDP per capita (current US \$)) (World Bank, 2014, GDP...). The financial situation of the country is as a consequence not onlyproduction of crude oil and gas, but responsible management of state wealth.

Natural phenomenon responsible activities in Norway originates in culture and tradition. The Scandinavian model is the extraordinary variety of social market economy. This uniqueness stems from the social acceptance for the use of tools (the tax system, social programs, income redistribution) in reducing disparities. Congenital egalitarianism constitutes the basic principle of a fair system by which individuals and groups should be the same as any other background. Egalitarian attitudes of Norwegian society are reinforced high availability of education and learning at all levels. Knowledge in addition to being an economic value, which enables the use of development opportunities ${ }^{10}$, affects the understanding and universal acceptance of responsible activities.

According to the results of K. Bachnik's digressions on culturally in the management process at micro scale, a nation's cultural characteristics are transferred in the professional sphere and influence the type of model order (Bachnik, 2012, p. 80-94). The author draws special attention to Scandinavian egalitarianism, the desire to adhere to the principles, the use of dialogue in decision-making, respect for privacy, the importance of collectivism in cooperation, neutrality and consensus in resolving

10 According the Ranking of World Bank Knowledge Economy Index (KEI) 2012 Rankings, Norway takes fifth position in the world as a Knowledge - based economy, http:// siteresources.worldbank.org/INTUNIKAM/Resources/2012.pdf. 
conflicts, building lasting relationships with stakeholders as distinctive cultural components of other nations.

The Fund is managed on behalf of the Norwegian people by a special unit of the Norwegian Central Bank, which is a state institution. Implemented tools and fund management style reflect the expectations of society and the state. The fund is a specific international version of the Scandinavian global economic model.

\subsection{Concept of Corporate Social Responsibility and sustainable development in Government Pension Fund Global}

The concept of sustainable development at the level of the organization is poorly defined and represents a new approach in the management sciences (Adamczyk, 2001, p. 32). The transformation the sustainable development concept from macro and micro level is defined as a sustainable business in English literature (Paliwoda-Matiolańska, 2014, p. 246). The organisation functioning in accordance with assumptions of sustainable development are called sustainable corporation. According to Banerjee's definition sustainable corporation isan organization that strives to increase the economic long-term value for shareholders, through the integration of economic, environmental and social opportunities to increase the value of corporate strategy (Banerjee, 2002, p. 107). In this sense, sustainable organizations can easily discern the four dimensions of a socially responsible organization, proposed by Dahlsrud (without the exposed dimension ofvolontariness). This causes difficulty in making a clear distinction between the activities falling under the implementation of the concept of corporate social responsibility and sustainable development at the level of the organization, which is the Fund.

The concept of sustainable development and CSR have more common characteristics than differences. The clearest ideological differences are: the level of implementation of the concept (CSR - scale micro SD - the whole globe, the country), the origin of the creation (Jonker, Reichel and Rudnicka, 2011, p. 41-42) and the expected time horizon (usually a long period of planning and implementation occurs in the case of sustainable development). Due to the international nature of the organization scale implementation of the concept CSR is comparable to sustainable development policy. In 2009, was developed by the Ministry of Foreign Affairs document "Corporate Social Responsibility in a Global Economy", which highlights the increased expectations of states to use the concept on a larger scale in order to emerge from the crisis. The publication of this document highlights two issues. The first highlights the strategic 
treatment of CSR by Norway as a way to mitigate the effects of the crisis and achieve competitive advantage. It extends the coverage by the adopted micro to macro minimum in Norway. The second point concerns the manner of introducing changes begins with the establishment of regulations, documents and regulations. A. Carroll locates "the legal regulations" in second place after the economic conditions.

The analysis of the degree of similarity, differences and relationships between two concepts should emphasize the specificity of the subject of analysis. The Fund is an independent organization, but operating within the state structures. As a rule, management style and operation shall be in accordance with the directions of its policies, including sustainable development. Louche and Lydenberg (2008) confirm that the attitude of the government to determine the sustainability of policy interpretation and approach to the concept of socially responsible (Bengtsson, 2008, p. ?). And Norway plays pivotal role in driving sustainability disclosure at a national and global level. High rank sustainability enforces a similar level of realization of the concept of CSR. The high efficiency of the fund is not limited to the success of the organization, but to the entire state.

Other characteristics of the two concepts are the same ${ }^{11}$. Corporate social responsibility is a tool for implementing the concept of sustainable development of the country at the level of enterprises/organizations. As noted by A. Rudnicka implementation of the concept of CSR may lead to more effective pursuit of the organization to implement the country's sustainable development policy (Rudnicka, 2012, p. 47-48).

The compared concepts mutually stimulate themselves. The first interaction expresses as the influence of corporate social responsibility on Sustainable development. In this direction of the action, CSR support the implementation of sustainable development through the use and promotion of internationally socially responsible behaviour. The second portion of influence refers to the need to respect the principles of sustainable development through the state public institution, which in this respect is the world leader. These feedbacks cause the maturity of responsibility, because they are carried out simultaneouslyat the national level and micro scale. High investor trustto GPFG is on the border of the trust the governments of Norway. In the future, the experience acquired by the Norwegian authorities is a combination of the active use of these two concepts and reputation (The Reputation Institute, 2005, p. 7-8), Norway could fulfill a niche by offer for other country the effective and responsible management of public assets.

11 Annex 1. 
The results of the WWF Report from 2008 onwards, indicate that there are many reasons for acknowledging Norwegian government as a world leader of responsible and effective way of investing and management. Oslo is indicated as potentially the world's capital of socially responsible investing, due to the current consistency and naturalness responsible activities (Innovest Strategic Value Advisors for the WWF in 2008, p. 70-71). Government Pension Fund becoming the best managed fund in the worldand Oslo - the SRI capital of the world would place Norway at the forefront of invest innovation in the future economy. It would also cause to recognize Norwegian fund as the most important tool for realising the state aims of promoting global sustainable development and tackling climate change.

\section{Conclusions}

In summary, the main purpose of the article and the detailed plans have been achieved. The Government Global Pension Fund of Norway is a resilient executor and promoter of CSR. Socially responsible activities are very mature in the fund. Conditions that maturity underlie Norwegian tradition and culture of the nation, which also determine the specificity of the economic model of Norway. When evaluating CSR, it is necessary to establish the Norwegian model because it creates the possibility to implement this concept in a very natural way. The common and popular applying of the CSR could improve competitiveness in the long-term in Norwayandmakes reducing the small differences in relation to the concept of sustainable development. In this country the concept of CSR could be included to the permanent element of the style of Norwegian management.

Governmental Pension Fund Global is an excellent example of proper relation between the priorities of socio-economic and environmental development. It is a balance between and a sense of justice. This relationship is the essence of the model of the Norwegian economy - the market mechanism and state intervention. The Norwegian approach shows that for sustainability responsibility is shared between business and the state.

The implementation of the assumptions of the CSR concept is the one correct way to sustainable development of an organisation, and then the state and the world. Functioning in accordance with the objectives of this concept increases stakeholders confidence, resulting in formation of a competitive advantage. 


\section{References}

Adamczyk J. (2001), Koncepcja zrównoważonego rozwoju w zarządzaniu przedsiębiorstwem, Kraków.

Anioł W. (2013), Szlak Norden. Modernizacja po skandynawsku, Dom Wydawniczy Elipsa, Warszawa.

Araszkiewicz K. (2008), Znaczenie norweskiej ropy naftowej i gazu w Norwegii, (in:) T. Dębowski, M. Sienkiewicz (eds.), Z badań nad geografia polityczna i gospodarcza, Wrocław.

Baberjee S.B. (2002), Organizational strategies for susatinable development, "Australian Journal of Managenent", No. 27.

Bachnik K. (2012), Skandynawskie uwarunkowania kulturowe w procesach zarzq̨dzania, CeDeWu, Warszawa.

Behrendt S. (2010), Sovereign Wealth Funds and the Santiago Principles, Carnegie Endowment, Washington.

Bengtsson E. (2008), A history of Scandinavian socially responsible investing, "Journal of Bussines Ethics", No. 82(4), DOI: 10.1007/s10551-007-9606-y.

Carroll A.B. (1991), The Pyramid of Corporate Social Responsibility: Toward the Moral Management of Organizational Stakeholders, Business Horizons.

Commission Of The European Communities (2001), Green Paper, Promoting a European Framework for Corporate Social Responsibility, European Commission, Brussels.

Council on Ethics, Council's Activities, (online), 20.01.2015, http://etikkradet.no/ en/councils-activities/.

Chmielak A. (2002), Instytucjonalne podstawy trwałości rozwoju gospodarczego, Wydawnictwo WSFiZ w Białymstoku, Białystok.
Davis K., Blomstrom R. (1975), Business and society: Enviroment and responsibility, $3^{\text {rd }}$ ed., McGraw-Hill, New York.

Dahlsrud A. (2008), How corporate social responsibility is defined, Wiley InterScience.

Fiedorczuk J. (2014), Rola Rządowego Funduszu Emerytalnego na tle problemów rozwoju społeczno-gospodarczego Norwegii, "Optimum”, No. 2(68), Białystok.

Filek J. (2013), Społeczna odpowiedzialność biznesu jako nowa wersja umowy społecznej, Księgarnia Akademicka, Kraków.

Government.no, Fund performance, (online), 14.01.2015, https://www.regjeringen.no/en/topics/the-economy/ the-government-pension-fund/government-pension-fund-global-gpfg/ fund-performance/id696854/.

Government.no, Market value, (online), 3.01.2015, https://www.regjeringen.no/en/topics/the-economy/ the-government-pension-fund/government-pension-fund-global-gpfg/ market-value-and-capital-inflow/ id696852.

Harrison L.E., Huntington S.P. (2003), Kultura ma znaczenie, Wydawnistwo Zysk i S-ka, Poznań.

Innovest Strategic Value Advisors for WWF (2008), Fund Management in the 21st Century: The role of sovereign wealth funds in contributing to a low carbon future, (online), 7.02.2015, http:// www.wwf.se/source.php/1215663/ Fund $\% 20$ Management $\% 20$ in $\% 20$ the\%2021st\%20Century.pdf.

Jonker J., Reichel J., Rudnicka A. (2011), Nowe horyzonty. Przewodnik 
po spotecznej odpowiedzialności i rozwoju zrównoważonym, Centrum Strategii i Rozwoju Impact, Łódź.

NBIM, History, (online), 31.01.2015, http:// www.nbim.no/en/the-fund/history/.

NBIM (2015), Responsible investment, (online), 4.02.2015, http:// www.nbim.no/en/responsibility/ responisble-investments/firm.

Norges Bank (2014), Annual Report 2013, (online), 14.01.2015, http://static. norges-bank.no/pages/98959/tekst/ Norges-Bank_Annuel_Report_2013. pdf.

Norwegian Embassy, The Norwegian Pension Fund - making ethical investments, (online), 17.01.2015, http://www.norway.ph/news/Business-News/The-norwegian-pension-fund---making-ethical-investments1/\#.VQ8wKhriWV4.

Nowiak W. (2011), Nordycki model „Welfare state" w realiach XXI wieku, Wydawnictwo Naukowe WNPiD UAM, Poznań.

OECD, Guidelines text and commentary, http://www.oecd.org/daf/inv/ mne/48004323.pdf.

OECD, OECD Principles of Corporate Governance, http://www.oecd.org/corporate/ca/corporategovernanceprinciples/31557724.pdf.

Our World (2010), Human Sustainable Development Index, (online), 8.02.2015, http://ourworld.unu.edu/ en/the-2010-human-sustainable-development-index.

Paliwoda-Matiolańska A. (2014), Odpowiedzialność społeczna w procesie zarządzania, $2^{\text {nd }}$ ed., C.H. Beck, Warszawa.
PRI, Signatories to the Principles for Responsible Investment, http://www. unpri.org/signatories/signatories/ ?country=Norway.

Rudnicka A. (2012), SCR - doskonalenie relacji społecznych $w$ firmie, Oficyna a Wolters Kluwer business, Warszawa.

Soskice D. (1999), Divergent Production Regimes, (in:) H. Kitschelt (ed.), Continuity and Change in Contemporary Capitalism, Cambridge.

SWF Institute (2014), Sovereign Wealth Fund Name, (online), 13.01.2015, http:// www.swfinstitute.org/fund-rankings/.

SWFI (2014), Linaburg-Maduell Transparency Index, (online), http://www. swfinstitute.org/statistics-research/ linaburg-maduell-transparency-index/.

The Reputation Institute (2005), World of Reputation Research, Analysis and Thinking - Building Corporate Reputation Through CSR Initiatives: Evolving Standards, New York, NYA doi:10.1057/ palgrave.crr.1540235.

Truman E.M. (2007), A Scoreboard for Sovereign Wealth Funds, Peterson Institute, Washington.

UNDP (2014), Human Development Report 2014, (online), 8.02.2015, http://hdr. undp.org/en/countries/profiles/NOR.

Wąsowska A., Pawłowski M. (2011), Metody pomiaru społecznej odpowiedzialności biznesu - przegląd literatury, "Przegląd Organizacji".

Whitley R. (2000), Diverent Capitalisms, Oxford.

World Bank (2014), GDP per capita (current US\$), (online), 8.02.2015, http://data. worldbank.org/indicator/NY.GDP.PCAP. $\mathrm{CD} /$ countries?order=wbapi_data_val- 
ue_2013+wbapi_data_value+wbapi_ data_value-last\&sort=asc.

World Bank (2013), Knowledge Economy Index (KEI) 2012 Rankings, (online),
31.01.2015, http://siteresources. worldbank.org/INTUNIKAM/Resources/2012.pdf. 
The book fits into a multidisciplinary research approach. The articles are the result of research conducted by eminent international economists, authors representing academic centres in different countries. The articles address current phenomena observed in the global economy. The authors do not aspire to comprehensively explain all the very complex and multi-dimensional economic developments, but illustrate many of these phenomena in an original way. The multi-threaded and multi-dimensional nature of the discussion in particular articles deserves attention. These include theoretical and methodological articles as well as the results of empirical research presented by the authors.

The book is addressed to those persons interested in issues of economics, finance, regional economy, and the management sciences. It can be valuable for economic practitioners, members of management and supervisory boards of companies, and financial analysts, and the articles may also be useful for academicians and students.

Piotr Urbanek, University of Łódź

\section{NBP Narodowy Bank Polski}

